\title{
MODELLING THE LEGACIES OF WAR VIOLENCE: VOTERS, PARTIES, COMMUNITIES
}

\section{Josip Glaurdić}

Institute of Political Science

University of Luxembourg

E-mail: josip.glaurdic@uni.lu

\section{Christophe Lesschaeve}

Institute of Political Science

University of Luxembourg

E-mail: christophe.lesschaeve@uni.lu

\section{Michal Mochtak}

Institute of Political Science

DOI: 10.20901/an.15.04

University of Luxembourg

E-mail:michal.mochtak@uni.lu

Review article

Accepted: December 2018

\begin{abstract}
Wars are extreme events with profound social consequences. Political science, however, has a limited grasp of their impact on the nature and content of political competition which follows in their wake. That is partly the case due to a lack of conceptual clarity when it comes to capturing the effects of war with reliable data. This article systematises and evaluates the attempts at modelling the consequences of war in political science research which relies on quantitative methods. Our discussion is organised around three levels of analysis: individual level of voters, institutional level of political parties, and the aggregate level of communities. We devote particular attention to modelling the legacies of the most recent wars in Southeast Europe, and we offer our view of which efforts have the best potential to help set the foundations of a promising research programme.
\end{abstract}

Keywords war legacies, post-conflict societies, elections, voters, parties, political competition

\section{Introduction}

How does war shape post-war politics? When is electoral competition in postwar societies determined by the war past, and when is it determined by the peacetime present and future? What are the conditions under which war becomes an integral part of post-war political narratives, practices, and insti- tutions? Post-war elections have attracted great interest from political scientists. That interest, however, has been primarily focused on the connection between electoral democratization and conflict. Voters' and political entrepreneurs' interests and electoral behaviour after the initial, temporally very limited, post-conflict period have remained lar- 
gely neglected by researchers, even though the effects of war reverberate long after the end of hostilities. War changes people and their communities. It forges distinct social groups bounded by their diverse and traumatic war experiences of migration, loss, illness, and death. It destroys polities' fabrics of mutual understanding and tolerance. And yet we have little systematic and theoretically advanced understanding of its impact on the nature and content of post-war political competition.

Systematising and theorising the study of post-war politics is, of course, a difficult task exactly because wars have such complex effects on both individuals and societies. In fact, even capturing the essence of those effects has proven to be a substantial challenge in the field, with significant differences in approach among scholars, at times guided by the lack of available data and at times by unclear methodological aims. Some authors have, for example, focused on individuals' personal experiences of combat or the feelings of trauma. Others have focused on the contextual or social experiences of exposure to violence. These different approaches have unsurprisingly led to often conflicting findings and limited theoretical advancements. This article presents our attempt at classifying the different approaches in the literature toward modelling the legacies of war, with the goal of advancing our understanding of the wars' impact on post-war politics. We centre our attention on studies utilising quantitative methods with relatively large samples and focusing on countries which have experienced conflict of a significant magnitude - regardless whether civil or international - and which have embraced some form of democratic competition in the post-war period. Our focus on quantitative, large- $\mathrm{N}$ studies is not grounded in the belief that this kind of re- search is empirically more valuable, but simply in the fact that this is the kind of research we do. Our choice inherently limits the reach of our review, though we would argue that it also improves its analytical clarity. We organise our discussion around three levels of analysis: individual level of voters, institutional level of political parties, and the aggregate level of communities. ${ }^{1}$

With this review article, we aim not only to identify the principal ways in which political scientists have tried to capture the impact of war on post-war politics, but also to offer our understanding of which approaches may provide the most fruitful way forward, particularly when it comes to the study of the political legacies of war in contemporary Southeast Europe. In our view, Southeast Europe offers the best opportunities for the comparative study of the effects of wars of different type (civil wars, wars of aggression, international interventions), outcome (defeat, victory, and stalemate), and character (ranging from lengthy skirmishes of low intensity to genocide) on the nature of post-war political competition. Our hope is that this contribution sparks interest among scholars of the region for the disciplined and methodologically advanced study of the concepts and dynamics we write about. The account we present here is by no means comprehensive, but rather a cross-section of the literature we believe has the greatest potential for the setting of the foundations of a promising research programme. In the sections that follow, we deal with each of the three levels of analysis in turn. The first section

\footnotetext{
These three levels of analysis also form the three distinct, though closely related, segments of our 5-year research project funded by the European Research Council Starting Grant No. 714589, titled "Electoral Legacies of War: Political Competition in Post-war Southeast Europe" (ELWar) and hosted by the University of Luxembourg.
} 
reviews the key findings in the literature on the voter-level effects of war and argues that the direction of future research should take into consideration in other social sciences, particularly in the economic psychology of risk formation. The second section reviews the relatively under-developed literature using quantitative methods in the study of postwar political parties. It argues strongly for the implementation of automated or computer assisted analyses of political text as the best way forward in analysing the effects of war on the behaviour of political parties and political entrepreneurs. Finally, the third section, dealing with the community-level effects of war, complements its literature review with a broader discussion about the practicalities of doing that kind of research in Southeast Europe.

\section{Voters' war experiences: Combatants, civilians, and war trauma}

A large body of literature is devoted to the impact of war experiences and war trauma on the lives of affected military personnel and civilians. Most of these studies, however, focus on stress and other psychological symptoms experienced by the individuals exposed to war violence. Relatively few authors address how individual war experiences and war trauma actually affect political behaviour. Our understanding of how exposure to various forms of war violence fits into the reality of voter choice is, therefore, limited and fragmentary at best. A perfect testament of this tendency can be observed in a recent review of the greatest advances in the study of various forms (i.e. not just economic) of retrospective voting in which war received just one short paragraph (Healy and Malhotra 2013: 295). The focus of this section of our article is exactly on the studies which connect war experiences and political behaviour - how they conceptualise and operationalise individual war experiences, and the consequences this has on their capacity to explain particular individual-level political behaviours. It is important to note that the overwhelming majority of the works dealing with these questions are founded upon analyses of various forms of public opinion surveys, with only a handful of studies employing (quasi)experimental designs with very limited analytical reach. The causal argumentation they present, therefore, needs to be considered rather cautiously.

In terms of measuring individual-level war experiences, the main distinction in the literature seems to be between the focus on the experiences of former combatants who actively fought or participated in the conflict and the focus on the experiences of civilians who were more or less unwillingly exposed to the conflict. The experiences of the latter group could be further subdivided into those which were personally or directly experienced, and those which happened to someone close like a friend or family member and were therefore experienced only indirectly. What exactly is measured in each of these types of war experiences varies substantially between studies. In samples with both veterans and non-veterans, one of the most common ways to distinguish between the two has been via a simple binary variable, indicating whether individuals served in the military or not. This has been a staple of research on the veterans of the various $20^{\text {th }}$ and $21^{\text {st }}$ century wars in the American context (e.g. Jennings and Markus 1977; Klingler and Chatagnier 2014; Teigen 2006, 2007). Since no additional information was used in these studies to determine whether the respondent actually saw combat, however, their ability to draw conclusions on the relation between combat exposure and political 
behaviour among military personnel has been limited. A more fruitful approach has been used in the studies on the consequences of the wars in former Yugoslavia, as well as the conflict between the Israelis and the Palestinians. Here, scholars have usually distinguished veterans from civilians by whether they actually fought in the wars (Massey, Hodson, and Sekulic 2003; Sandovici and Listhaug 2012; Strabac and Ringdal 2008), with some also employing information about the duration of soldiers' service in a combat zone (Grossman et al. 2015).

When it comes to measuring war experiences of civilians, on the other hand, the literature has suffered from an apparent lack of conceptual and theoretical clarity in three different, but closely related, ways. First, the distinction between direct and indirect war experiences has often been blurred. Dyrstad (2012, 2013), for example, has measured "direct individual exposure", but operationalised it as whether the respondent had a close friend or family member die or disappear, which is in fact an indirect war experience. Massey et al. (2003) have calculated a war experience index based on both personal experiences (such as whether one's life was endangered or whether one was wounded) and events that happened to friends and family members (see also Canetti et al. 2017; Canetti-Nisim et al. 2009; Hirsch-Hoefler et al. 2016). Moreover, they included a separate measure for having been in personal danger during the war, which created a conceptual overlap between their independent variables. In this line of research, arguably only Sandovici and Listhaug (2012) and Strabac and Ringdal (2008) have appropriately distinguished between war events experienced personally and events experienced by someone close to the respondent. Both studies concluded that direct and indirect experiences of war can have different political ramifications (of which more below).

Second, many studies have created rather simple sum indices of concrete war experiences to measure someone's exposure to war (Blattman 2009; Canetti et al. 2017; Canetti-Nisim et al. 2009; Massey, Hodson, and Sekulic 2003; Solomon and Lavi 2005). The main problem with this approach has been the qualitative difference between those various experiences. For instance, in Massey et al. (2003) a family member wounded and a family member killed were equally valued in the calculation of the war experience index. Additionally, multiple concrete war experiences such as being a refugee, life endangerment or starvation might have been related to the same event, which may then have been counted multiple times. A better approach would likely be to focus on a limited number of specific experiences and to treat these experiences as qualitatively different, or to give certain experiences a larger weight through factor analysis (Kijewski and Freitag 2018).

And third, even when authors have looked at individuals' veteran status, and their direct and indirect war experiences separately, they have always viewed the impact of one type of war experience on political outcomes as independent from or simply additional to the impact of another war experience. Since these experiences are not mutually exclusive, it is possible - even likely - that the different types of war experiences interact with one another. For instance, how someone's direct war experience, such as being a refugee, leads to certain policy preferences could be conditional on whether that person also lost a family member. In other words, the literature lacks theoretical and empirical clarity when it comes to the intersectionality of 
war experiences, i.e. how they moderate or amplify the relationship between other war experiences and political behaviour and attitudes.

When it comes to the study of the political implications of prior military experience, we can say that it has a long - though patchy - tradition, particularly in the US context. After WWII, there was a concern that the men returning from Europe and the Pacific would be more authoritarian because of their service and combat exposure (Teigen 2007). Schreiber (1979) investigated this question by looking at the difference in the survey responses between men who served in the military and men who did not. He found that veterans, while having more positive attitudes toward the military, were not more authoritarian than non-veterans. His results additionally showed that military service had no impact on faith in the government. A more thorough and empirically more advanced examination was arguably performed by Jennings and Markus (1977), who conducted a two-wave survey of 410 male high school seniors between 1965 and 1973. Their study looked at how service in the Vietnam War affected respondents' trust in the government. They concluded that while political cynicism among Vietnam veterans was comparable to that among non-veterans, veterans did have more faith in the federal government.

More recently, Klingler and Chatagnier (2014) analysed the survey responses of nearly 36 thousand US adults and concluded that veterans were more right-wing on both economic issues such as the minimum wage, and social issues such as abortion and immigration. Veterans were also found to be more likely to favour military action in response to, for instance, efforts to secure oil or protect allies. These findings stand in contrast to those of Teigen (2007), who used a survey of about 1200 US adults to look at the party preferences of veterans and non-veterans in the 2004 US presidential elections, and found no significant difference between the two groups. This somewhat surprising finding could perhaps be explained by the existence of a countervailing force, namely that the military also places a strong emphasis on communitarian values, or it could simply be the product of the historical juncture the United States found itself in at the time of the survey, i.e. in the middle of a highly unpopular war which was started under false pretences. In his 2006 study, however, Teigen did find a significant difference between men who had combat experience and those who did not. His examination of survey data including more than 635 thousand US adult males between 1972 and 2004, found that men who served in the military were generally more likely to vote, with one exception: Vietnam War veterans. The design of the study did not give many options for causal argumentation, but we can hypothesise that higher turnout rates among veterans could be due to three reasons: veterans already having a strong sense of civic duty prior to joining the military, the military instilling civic norms and values in its recruits, and the presence of strong veteran interest groups. All these factors, of course, falling by the wayside if the combat experience is as unpopular and ends as ignominiously as was the case with the war in Vietnam.

The evidence on the difference between the political views and actions of veterans and non-veterans outside of the US context is also mixed. Grossman et al. (2015) looked at male soldiers who served in the Israeli Defence Forces between 1998 and 2003 (roughly corresponding with the events 
of the Second Intifada), comparing soldiers who had combat exposure to soldiers who did not. Their results showed that the former were less likely to have conciliatory attitudes in favour of a peaceful settlement of the conflict, and were more likely to vote for hard-line parties. Contrary to Teigen's (2006) findings, Grossman et al. concluded that combat exposure resulted in lower levels of political participation (though they did not look at voting). In studies focusing on the wars in former Yugoslavia, studies found no difference between veterans and non-veterans. Support for ethnic nationalism and liberalism (Massey, Hodson, and Sekulic 2003), ethnic prejudice (Strabac and Ringdal 2008), and optimism about the future do not seem to depend of having fought in the wars (Sandovici and Listhaug 2012).

The study of how the war experiences of civilians affect their political behaviour and attitudes is similarly inconsistent and often contradictory, likely dependent on social and historical context, as well as on the different operationalisation of the principal dependent variable capturing the legacies of war. The main focus of most authors have been political attitudes, with only one study looking at the relation between war experiences and actual political behaviour (Blattman 2009), though with a highly context-specific set of war experiences which dramatically limits the study's generalisability. When it comes to political attitudes, the picture that emerges is rather mixed. Massey et al. (2003) found that war experiences in Croatia were positively related to ethnic nationalism, but unrelated to the support for liberalism. In Kosovo, war experiences seem to have reduced the trust individuals have in the people in their neighbourhoods (Kijewski and Freitag 2018). Strabac and Ringdal
(2008) demonstrated that, while indirect war experiences increased ethnic prejudice in Croatia, direct war experiences did not. Sandovici and Listhaug (2012) found that in Bosnia and Herzegovina direct experiences reduced optimism while indirect experiences increased it. Dyrstad (2012) looked at how indirect war experiences were related to ethno-nationalism and authoritarian values in Bosnia and Herzegovina, Croatia, and Kosovo, finding that respondents' sense of ethno-nationalism was only affected by exposure to war-related violence in Croatia, but not in Bosnia and Herzegovina and Kosovo. In her 2013 study focused on the same countries, Dyrstad also established that indirect war experiences lead to authoritarian values, though crucially only if they also resulted in post-traumatic stress disorder (PTSD).

Arguably the most elaborate work on the topic of civilian war experiences has been done by Canetti-Nisim et al. (2009), Canetti et al. (2017), and Hirsch-Hoefler et al. (2016). They developed a distress-based model of how war experiences affect attitudes toward peace. The model argues that the exposure to violence leads to psychological stress, which in turn leads to an increased threat perception of the enemy. This results in an "ethos of conflict", comprising of beliefs related to the justness of goals, victimization, security, delegitimization of the opponent, patriotism, unity, and peace. This ethos of conflict subsequently shapes political attitudes. The model has proven effective in explaining exclusionist attitudes in Israel toward Palestinians (Canetti-Nisim et al. 2009), and attitudes toward what a peace settlement with the Palestinians should look like (Canetti-Nisim et al. 2009; Hirsch-Hoefler et al. 2016; also see Solomon and Lavi 2005). 
We believe that this line of argumentation offers great promise as it focuses on the respondents' actual feelings of trauma which are partly dependent on war experiences, but partly also on the individuals' capability to cope. The greatest challenge for future research efforts lies in creating a portable theoretical grounding which will help us expose the mechanisms behind the effects of exposure to different war experiences (and the possible cross-generational transfer of trauma) on political attitudes. In our opinion, one part of the answer could be in learning from and applying some of the findings in economic psychology, namely on the impact of traumatic experiences on risk aversion. Apart from a couple of exceptions (Eckel, El-Gamal, and Wilson 2009; Voors et al. 2012), the near consensus of this literature is that traumatic experiences - whether it is floods (Cameron and Shah 2015), economic depression (Malmendier and Nagel 2011), terrorism (Sacco, Galletto, and Blanzieri 2003), losing a child (Bucciol and Zarri 2015), or war (Kim and Lee 2014) - make people more risk averse, possibly even permanently (Callen et al. 2014). In other words, war-related trauma could, through higher risk aversion, lead to changes in individuals' political preference functions when it comes to personal as well as economic security (Glaurdić and Vuković 2018). These changed preference functions would in turn, in interaction with the supply of political options specific to the social and historical context, lead to the observed nature of post-war electoral competition.

Of course, there are a number of challenges that need to be addressed if we are to succeed in exposing this dynamic. Two of them particularly stand out. The first challenge is in appropriately modelling the legacies of war violence on the individual level in a uniform and broadly applicable way. Guided by Canetti-Nisim et al. (2009) and their finding that it is the feeling of psychological distress that matters when it comes to pinpointing the determinants of post-conflict political attitudes, the individual voter level section of our project which employs public opinion surveys, experimental, and quasi-experimental methods captures trauma exactly by inquiring about the individuals' different dimensions of their possible war-related psychological distress. Here we follow the scales employed by the South East European Social Survey Project in order to make our findings comparable to the data it collected a decade and a half ago (Simkus 2007). The second challenge in exposing the mechanism connecting war trauma and political behaviour lies in designing studies which can improve on conventional public opinion research when it comes to making causal inferences. As stated above, studies utilising, for example, experimental and quasi-experimental designs to deal with the impact of the legacies of violence on any kind of political behaviour are few and far between (e.g. Blattman 2009; Montalvo 2011). That is obviously partly due to the nature of the subject matter, but if the field is to make significant strides in explaining the effects of war legacies on post-war voter choice, methodological approaches enabling higher levels of causal inference will have to be employed to a far greater extent than has been the case thus far.

\section{Political parties and war legacies: Institutionalising past into present}

Political parties as key actors of political change play an important role in the creation of sustainable peace, stability, and democracy. This claim is true for both functioning democracies as well as all 
other forms of regimes either stable or undergoing political or social transformation (van Biezen 2004; Bille 2001). Although political parties have been possibly the most studied political actors for decades, the effects of war or violent conflict on their internal organisation, policy preferences, or mobilisation efforts have been very rarely addressed in any systematic or theoretically informed way. This is surprising since many traditional political parties in Europe, Asia, Africa, and Latin America were forged in or at least affected by violent conflict at some point in their history. Just as is the case with individuals and communities, these experiences are uniquely transformative for political parties as well. Their effects could be potentially significant years or even decades after the conflict has ended, influencing different dimensions of parties' political profile and activities.

Most of the research dealing with war legacies in the context of parties focuses on the transformation of former rebel groups into peacetime political institutions and their adjustment to the new democratic arena of competition (e.g. Ishiyama 2014; Ishiyama and Marshall 2015; Manning 2008). In fact, rebel groups and former fighters are not merely the central components of the mainstream research approach to the study of war legacies and party politics - they are a hegemonic one. Although the relevant literature addresses a variety of topics such as party organization, party leadership, surviving war time networks, or party and electoral systems, the focus is temporally rather narrow, and it often covers only the immediate period of post-conflict negotiations. In this context, political parties or their organisational proto-forms (e.g. rebel groups, fighters, guerrillas) are mostly studied through the four different phases of conflict and peacebuil- ding they are part of: conflict causation, conflict settlement, post-war transition, and post-war democratization (Ramsbotham et al. 2016; Zeeuw 2008). With this limited timeline of interest, what we are missing is an entire body of research that should go beyond rebel groups and their transformation and should try to cover the long-lasting effects of war on political parties in a comparative perspective. What happens not only to rebel groups, but also to "conventional" political parties after the war is over? In which ways is the legacy of war relevant even after the usual phase of post-war democratization is finished? How do we observe, theorise, and study these war legacies? What kind of evidence can we collect and analyse in a rigorous and comparative fashion?

The existing literature on post-war political parties could roughly be divided into two groups which could best be termed structural and functional. The structural group covers predominantly the structural characteristics of political parties and their systems. Typical examples would be studies of party organisation (Sindre 2016; Reilly 2006), party leadership and candidate recruitment (Khazen 2003; Lyons 2016; Ishiyama and Marshall 2015), various networks of cooperation (Taleski 2012), the party system itself (Jarstad and Sisk 2008; Goeke 2016), typology and characteristics of political parties (Reilly and Nordlund 2008), electoral system designs and their effects on political parties (Reilly 2008; Ishiyama 2014), or institutional restrictions such as party bans imposed on political representation (Basedau and Moroff 2011). The functional group, on the other hand, focuses on the political parties' actions and functions. Typical examples would be studies of legitimacy (Taleski 2012; Lyons 2016), war-related policy agenda (Taleski 2012), role of ideology (Whiting 2016; Gadjanova 2015), 
or effects of foreign aid (Marshall 2017; Nenadović 2010). This division should not be understood as rigid, since none of the referenced works focuses on one issue only. However, what virtually all of them have in common is their focus on the immediate aftermath of armed conflict, as well as their focus on the transformation of former fighting groups into political parties.

These works also have much in common when it comes to their methodological approaches. Most published research centres either on one case or on a small number of cases which are examined mostly through qualitative empirical strategies like oral histories or in-depth archival and historical research (Reilly 2001; Sindre 2016). Only a handful of studies have approached the analysis of political parties in post-conflict environments from a medium- or large-N quantitative perspective. Manning and Smith (2016) use a sample of 65 post-conflict settlements to test what the conditions are under which rebel groups successfully incorporate into democratic politics when civil wars end. Ishiyama (2014) uses a sample of 92 countries with civil war experience to study the effects of conflict on the characteristics of post-conflict party systems and their stability. Marshall (2017) uses a sample of 112 rebel parties to test their long-term viability in post-conflict elections following negotiated settlements. Ishiyama and Marshall (2015) build a unique dataset of electoral candidates in post-conflict Nepal to examine the recruitment and nomination strategies of former rebel groups. The same authors in their 2016 study use a sample of 69 post-conflict settlements to test whether the transformation of rebel groups into political parties leads to the development of a durable peace after a civil war. Most recently, Matanock (2018) uses a sample of 122 dyadic settlements to study under what conditions civil conflict settlements bring former combatants into normal politics as political parties.

As can be seen from this overview, the current stream of literature provides a rather limited scope of attention that omits a big part of potential empirical evidence on the legacies of war and their relevance for political parties. The legacies of war in parties' platforms, organisations, or mobilisation strategies are arguably not directly modelled at all but are rather asserted in a binary fashion depending on their potential status as former rebel groups. However, almost all "old" or "traditional" parties in Western Europe, not to mention most political parties in Southeast Europe, have been massively affected by war at some point of their evolution and development, and some of those effects reverberate in the lives of these parties to this day. The literature's existing focus on political parties in immediate post-conflict settings does not provide much guidance for studying those more long-lasting war legacies. Although partial inspiration can be found in the extensive literature on political parties in consolidated democracies (Katz and Crotty 2014; Hershey 2017) or in the research concerning general historical legacies and political parties (Crawford and Lijphart 1995; Mair 2004), the fact remains that a whole branch of research on the effects of war on post-conflict political parties still needs to be established. In terms of the previously presented timeline with the four phases of conflict causation, conflict settlement, post-war transition, and post-war democratization, we can say that a study of the fifth phase which could be defined as post-war consolidation and routinization of party politics needs to be created.

We propose that this need can be systematically best addressed by utilising automated or computer assisted analyses 
of political text based on modern tools of natural language processing (NLP). Since we believe that the legacies of war reverberate through party politics for a long time after the conflict has ended, our overall goal should be to find out what role the war past plays in everyday politics and how it evolves over time. In this context, the view of political parties as uniform institutions that interact with each other in the political arena should be eschewed. Instead, political parties in their traditional sense should be deconstructed and analysed as platforms of organised individuals who reveal their preferences and positions on an everyday basis and who define what party politics means (Krehbiel 1993; Itzkovitch-Malka and Hazan 2017; Dewan and Squintani 2016). To be more precise, we should particularly be interested in who talks about the war past (or war-related present and future!), how, when, and to which audiences. The primary source of data in this context is raw text, often a piece of writing or a transcript of the spoken word that is cleaned, analysed, and interpreted. Our societies produce mountains of texts that are political in nature on a daily basis which have been virtually impossible to process systematically by an individual or a small group of collaborators through what is known as close reading. Recent technological and theoretical advances in computational content analysis, however, have changed that dramatically.

The application of natural language processing tools to the study of war and war-related issues has so far been very limited and almost exclusively focused on political debates in the United States (e.g. Kriner and Shen 2014; Schonhardt-Bailey 2005). More generally, this approach is penetrating mainstream political science only slowly, mostly in the studies of parliamentary and campaign speeches, media discourse, and social networks (Baturo, Dasandi, and Mikhaylov 2017; Crowley, Watson, and Waller 2008; Proksch and Slapin 2015). However, the available tools are not reserved solely to these domains and could be applied to all sorts of social science problems and sources. News articles, debate transcripts, political blogs, media reports, social media posts and tweets are all unique and invaluable sources of information that can - thanks to new software and hardware advances - be processed and analysed in a variety of languages, including the languages of Southeast Europe. This presents a tremendous opportunity to address the most difficult challenges of collecting data on political parties in a more systematic and unbiased way.

In this context, the text as data approach is a key strategy for the study of political parties in Southeast Europe dictating what data need to be collected and how they can be analysed. In ELWar we focus our attention primarily on the evolution of war-related political discourse in Bosnia and Herzegovina, Croatia, and Serbia, and we try to understand what role war continues to play in the political lives of these countries how it is used and abused by political entrepreneurs and their followers in political arenas and in their daily interactions with the world around them. We have, for example, collected transcripts of debates in each of the national parliaments of our interest for at least 15 years of their post-conflict existence using various scraping and cleaning tools we developed ourselves on top of available programming packages. The result is a set of three corpora for the three parliaments that were further populated with meta-information identifying speakers, their personal characteristics (including their war pasts), and policy agendas on the level of single speeches. This gives us a massive source of information on 
political preferences and positions of individual MPs and, when aggregated, whole political parties. This approach paired with our analyses of other forms of public discourse in both conventional and social media - goes far beyond the mainstream studies of party manifestos, official party documents, and positions of the most prominent political figures which we also utilise. In other words, we cover the entire political spectrum of discourse and debate in the period of more than a decade and a half in countries with very similar, yet different, war histories and war legacies.

The study of war legacies in this context represents a unique opportunity where a number of NLP tools can be applied. Through these tools we can, for example, trace the development of topics we are interested in (counting and weighting of n-grams), properly identify and label these topics (topic-modelling), scale the evidence on a single (Wordfi$\mathrm{sh}$ ) or multiple scales (Wordscores), understand the contexts in which certain particularly war-past-related - concepts occur (keywords in context, LSI models, word2vec models), detect actors, organizations, or places (named entity recognition), understand the semantic structure of a written and/or spoken text (semantic network analysis), measure sentiment (sentiment analysis), or ultimately build complex machine-learning algorithms based on neural networks in order to get closer to a state where computer programs can read and understand natural language for us. This is just a fraction of opportunities we have at hand that can be used for the study not just of war legacies, but also all other relevant issues in political science.

This approach is however not the only strategy how political parties in post-conflict societies can and should be studied. The body of literature on political parties, their leadership, stru- ctures, and mechanisms of mobilisation is a fruitful source of inspiration which should be built upon and expanded. Text as data approach should therefore be combined with more conventional strategies in order to provide a broader scope for studying party politics. In the fall of 2018, we launched what will be an annual expert survey focusing on party positions in Southeast Europe which expands on the existing datasets on party positions and preferences like the Manifesto Project or the Chapel Hill Expert Survey (CHESDATA 2018; Lehmann et al. 2017) by including questions on the parties' attitudes toward the war past. For illustrative purposes, our Figure 1 shows the opinions of the experts we surveyed on the Croatian parties' left-right placement and their attitudes toward acknowledging harmful acts committed against other ethnic groups during Croatia's war for independence (Lesschaeve and Glaurdić, 2018). As is immediately apparent, this issue is perceived to be at the core of the ideological divide on Croatia's party scene.

The study of political parties has always been challenging, since access to politicians, their preferences, as well as many of their actions, has been limited. Text as data approach and the NLP tools of computational content analysis represent a solid strategy of collecting and processing relatively unbiased data. This approach and the tools it is built upon are by no means without shortcoming, but recent years have shown how powerful they can be if designed and utilised properly. The latest advances of multinational tech companies continue to show us the future of the industry and the future of our understanding of social as well as political interactions. Machine and deep learning, neural networks, and super computers are already affecting our lives tremendously. We believe they could also help transform how we as po- 
Figure 1. Attitudes of Croatian parties toward the war past, 2018 expert survey results

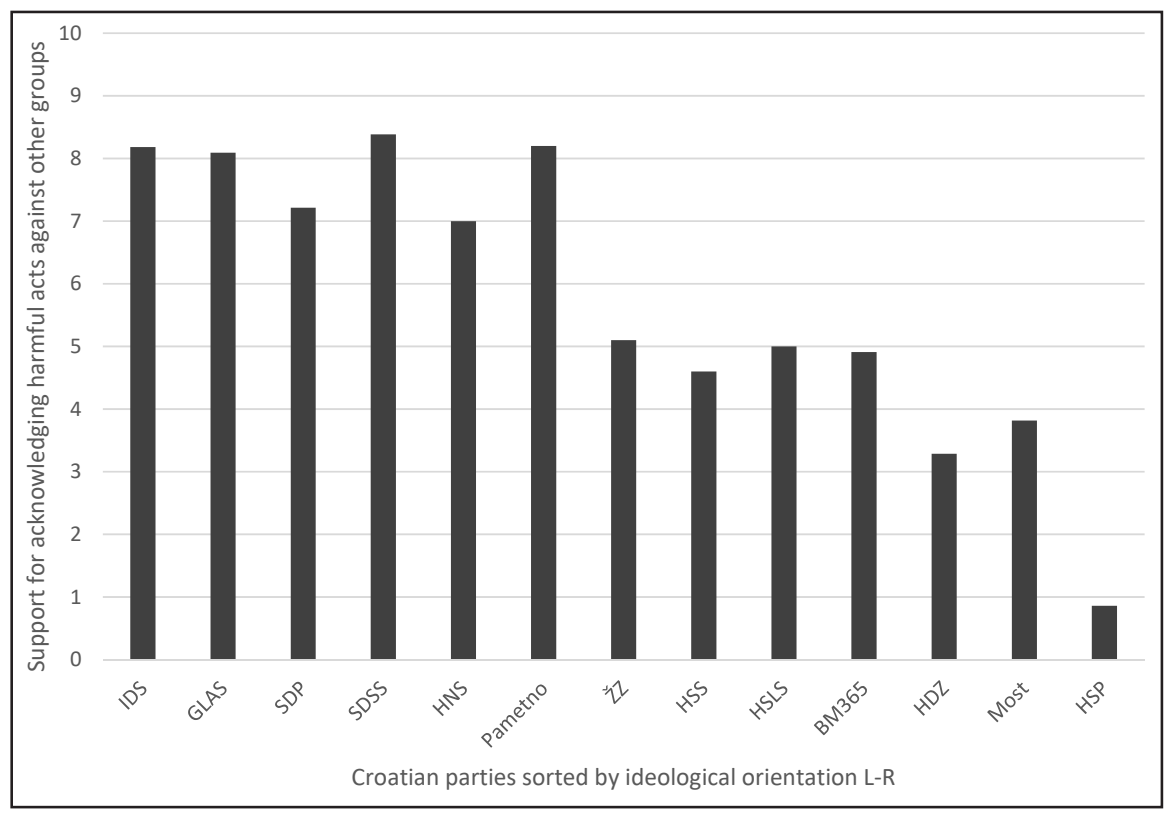

litical scientists understand the ways in which polities absorb the (war) past and turn it into (electoral) present.

\section{The social dimension of war legacies: Communities and experiences of violence}

Wars are, by their very nature, unevenly distributed social events. Their consequences are embedded in the particular context of space and time where and when different forms of violence take place. Individual-level data can only go so far in capturing this social nature of war and its legacies. If we are to understand the full nature of the consequences of war violence, we have to capture their essence in the pattern of their geographic distribution and temporal evolution. This approach, as anything in social sciences, has its trade-offs. On the one hand, researchers must be cognisant of the pitfalls of ecological fallacy and must be careful not to extrapolate aggregate-level findings onto the individual level. Aggregate-le- vel data is primarily useful when explaining aggregate-level phenomena. On the other hand, however, the quality of available aggregate-level data - particularly in more recent post-conflict societies - frequently surpasses the quality of individual-level survey data. The potentially fatal problems with sampling and self-reporting biases in public opinion surveys in post-conflict societies can be circumvented with quality aggregate-level data. The challenge is, of course, in finding such data on the level of meaningful sub-national or national communities - settlements, villages, cities, municipalities, regions, states, or any other geographically clearly defined areas. This often entails a painstaking combination of archival work as well as data collection, clean-up, and analysis, which takes time and requires a diverse methodological toolbox. We believe, however, that the potential benefits could be enormous, as this research has the capacity to dramatically alter the direction of our discipline. 
Modelling the effects of war and destruction on some form of aggregate level has presented a substantial challenge for scholars in a variety of fields beyond political science: from geography through sociology to economics. This challenge has been answered with an increasing level of innovation due to the availability of newer forms of data and data collection methods, such as satellite imaging (e.g. Witmer and O'Loughlin 2009). In development and urban economics, the focus has largely been on the destruction of physical and human capital. Davis and Weinstein (2002), for example, have studied the effects of Allied bombing on Japanese city growth after WWII and Brakman et al. (2004) largely replicated their study in the case of Germany. Both studies modelled the effects of Allied bombing using local estimates from the immediate post-war period regarding the destruction of housing stock and the number of casualties, and they both found the effects on city growth to have been only temporary at best. Miguel and Roland (2011), on the other hand, used US Air Force bombing intensity data on the level of Vietnamese districts and reached a similar conclusion, namely that physical destruction had no effect on post-war economic development of Vietnam. Vonyó (2012) also used the German WWII housing stock destruction figures and complemented them with the figures for German expellees from various East European lands in his study of the dislocation of the post-war West German economy and the effect of the drastic labour expansion on the rural economy. The debate on the comparative effects of physical versus human capital destruction was addressed in arguably the most innovative way by Fabian Waldinger in his 2016 study of the impact of Allied bombing and the Nazi dismissal of scientists on the productivity of German universities. Echoing the findings from other studies, human capital costs proved to have much larger negative effects on scientific output than physical capital losses.

When it comes to political science, we can say that aggregate-level data capturing the effects of war have been used primarily for two purposes: as higher-level controls in individual-level public opinion or experimental studies, or as more or less principal explanatory variables in studies where the dependent variables are also modelled on the aggregate-level. The use of aggregate-level data to capture contextual information regarding the possible effects of war has been a staple of individual-level public opinion research in political science for some time. Most often the data being used have been either binary variables or national-level casualty statistics in large pooled survey datasets. For example, Kostadinova (2000) used a series of simple binary variables to model Central and East European countries' World War II and Soviet-era pasts to explain the differences in individual respondents' support for NATO membership. Gabel and Palmer (1995) and Gabel and Whitten (1997) used national-level World War II casualty figures in pooled Eurobarometer surveys to expose the sources of difference among respondents when it came to their support for European integration. And, similarly, Allam and Goerres (2011) used those same casualty figures to explain the differences in support for the Euro among respondents from Central and East European countries. Interestingly, the conclusion of all these studies has invariably been that respondents coming from countries with stronger legacies of violent conflict were more likely to support various forms of European integration, suggesting that the memories of conflict are crucial for the continued support of the European project. Outside of the European context, the use of aggregate-level contextual data in public 
opinion and experimental research has largely focused on the United States with its excellent county-level and congressional district-level data on casualties in the wars in Vietnam, Iraq, and Afghanistan. The dependent variables of interest have usually been levels of support for the war effort or the levels of support for the incumbent administration responsible for the war operations (Althaus et al. 2012; Gartner et al. 1997; Kriner and Shen 2012), with the general conclusion that local losses matter more than national, and that incumbents' votes are negatively affected by higher casualty figures.

Political science research projects modelling the effects of war on the aggregate level and at the same time attempting to explain aggregate-level phenomena have focused their attention on similar issues, such as incumbency in the US context (Carson et al. 2001; Karol and Miguel 2007; Kriner and Shen 2007) or support for European integration in the post-communist context (Glaurdić and Vuković 2015). They have also, however, expanded the reach of our understanding of the political legacies of conflict by shedding light on deep, historically-rooted, political developments of almost cleavage-like character. Three projects are notable in this regard. Glaurdić and Vuković in their 2016 study track the evolution of the pattern of electoral results in the two decades after Croatia's war for independence. They find that the exposure of the local communities to war violence (proxied by the census figures for disabilities caused by the war) remains the strongest and most stable predictor of electoral fortunes, with the areas more exposed to war violence disproportionately supporting the centre-right Croatian Democratic Union (HDZ) which led the country into and throughout the war. Hadzic et al. (2017) find something similar in Bosnia and Herzegovina. They use a more complex battery of measures of the effects of war by looking at casualties, refugees, locations of wartime prison camps, and the estimates of physical destruction on municipal level, and they find all these measures to be solid predictors of the electoral support for ethnic parties in Bosnia and Herzegovina even two decades after the war had ended. Finally, Rozenas et al. (2017) expand the time-frame even further by using archival sources on Stalin's purges of the Ukrainians in the 1940s to show that the pattern of these purges determines the pattern of electoral support for pro-Russian and anti-Russian forces in Western Ukraine to this day.

This research holds great promise as it could provide a necessary revision of our understanding of such critical political phenomena as party mobilisation, political uses of historical memory, and cleavage formation. For example, the canonical work of Lipset and Rokkan (1967) on cleavage structures, party systems, and voter alignments that has influenced generations of researchers in comparative politics makes little mention of war as a phenomenon of any real impact on the nature of postwar political competition. This reluctance to consider war - particularly war of such monumental proportions as World War II - as an independent factor of influence on the formation of political cleavages, party systems, and voter alignments was carried over into the work of many who followed in Lipset and Rokkan's footsteps. From research on post-World War II West European polities (e.g. Barnes 1967; Baker, Dalton, and Hildebrandt 1981; Mair 1990) to research on post-communist Eastern Europe (e.g. Kitschelt et al. 1999; Tworzecki 2003; Tucker 2006; Rohrschneider and Whitefield 2009), the vast disparities in war experiences of individuals, communities, and po- 
litical organisations seldom featured as a variable of any meaningful impact on the nature and content of political competition, let alone as a political phenomenon meriting systematic theoretical and practical explanation. Aggregate-level research on the political legacies of war therefore has the potential of offering a welcome correction to some of the most long-standing and broadly held views in our discipline. It must be noted, however, that there are also important barriers to success.

Most obviously, there is the problem of data availability. Capturing the effects of war on spaces and communities is a complex matter, but we can identify five broad groups of data that could - taken together - get close to fulfilling the task: 1) data on military and civilian deaths, 2) epidemiological data on military and civilian injuries and illnesses, 3) population displacement data, 4) data on veteran status and various forms of postwar social benefits, and 5) estimates of destruction of physical capital. A limited number of conflicts generate solid data in any, let alone all five, of these groups. Even when they do, a diverse set of multidisciplinary skills is needed in order to properly execute appropriate empirical strategies. As already noted, a historian's or ethnographer's deep understanding of the dynamics of the conflict and the post-conflict period needs to be paired up with an economist's or statistician's understanding of different methodological techniques. One recent example will perhaps demonstrate that this is not easy even in very competent teams which produce highly-cited research in the best journals. Adena et al. (2015) in their excellent study of the impact of exposure to radio broadcasts on the spread of Nazi support in Weimar Germany use the figures on county-level supplementary assistance for World War I veterans as a proxy for the actual num- ber of "World War I participants" in each county. They do that although these figures represent merely ad hoc financial transfers by the county authorities in one year (1929), which were furthermore not subject to national-level legislation, but instead dependent on the health of the local authorities' budgets. Many cash-strapped counties thus provided no supplementary assistance whatsoever, which in Adena et al.'s interpretation would mean that these counties had no World War I "participants" at all. Unfortunately, Koenig (2015) and Satyanath et al. (2017) do not go back to the original source of data (Statistisches Reichsamt 1933), but instead take Adena et al.'s data uncritically and repeat the same mistake. These studies' non-findings regarding the impact of exposure to WWI violence on Weimar politics is therefore unsurprising.

Unlike most other post-conflict environments, former Yugoslavia's successor states - and in particular Croatia - offer some of the best data for the study of the political legacies of war. The wars in Croatia, Bosnia and Herzegovina, and Kosovo have been arguably the most documented conflicts since World War II, with a wealth of archival and statistical sources generated by the various domestic and international legal institutions, bureaus of statistics, as well as organisations of the civil sector. What is especially important to note is that new sources and new data are still being generated and distilled for the interested public, particularly when it comes to the often-competing efforts of several organisations in compiling the lists of war dead. If we use the aforementioned classification of war legacy aggregate-level data into five groups, we can say that Croatia, for example, on the level of its 556 municipalities: 1) has publicly available data for population displacement; 2) has publicly available data for 
Figure 2. Modelling the consequences of war violence in Croatian municipalities

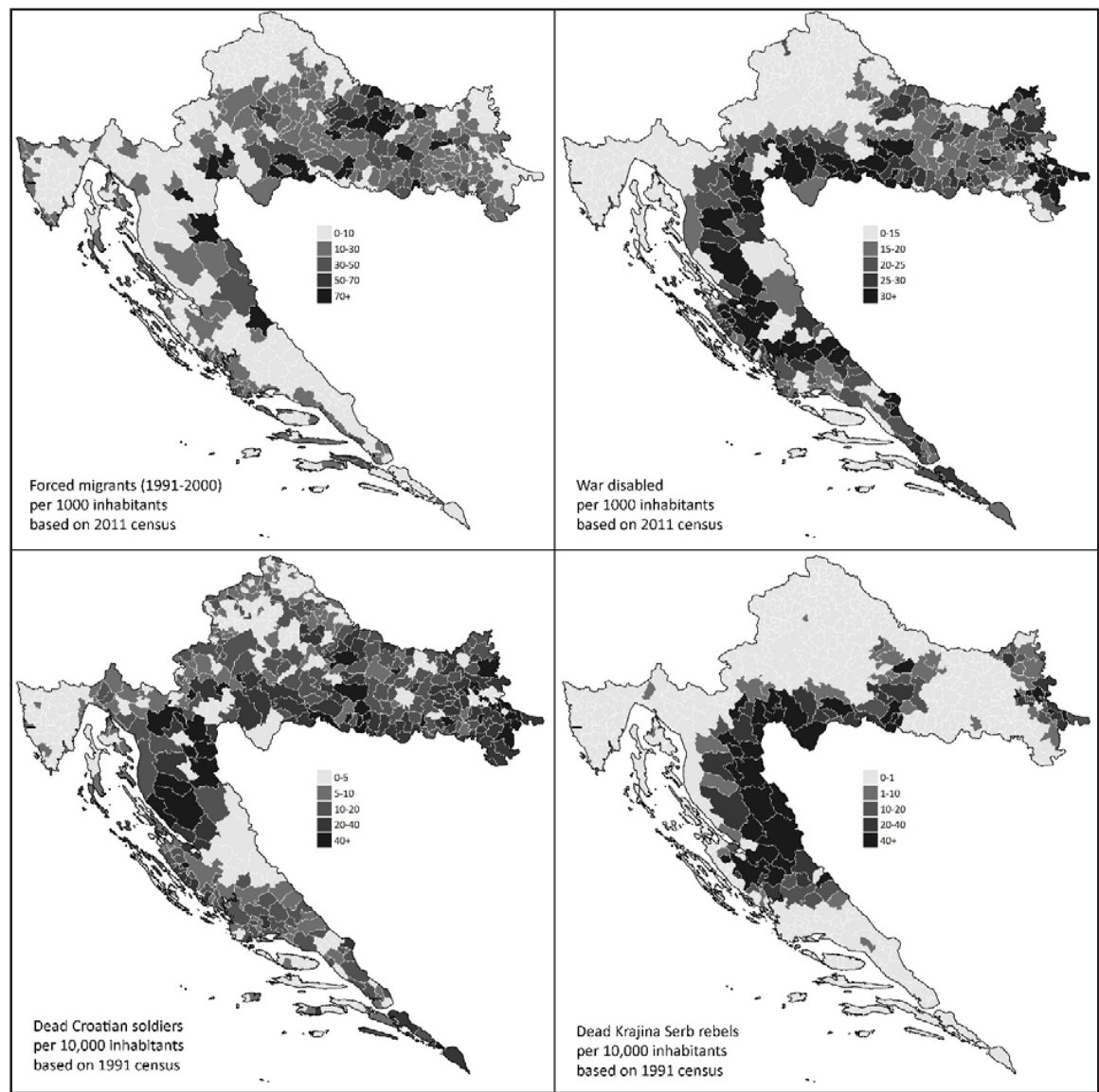

war-related disability; 3) will eventually have publicly available data for civilian and military deaths on both sides of the conflict; 4) has publicly unavailable data for veterans; and 5) has very limited and flawed data on physical destruction.

When it comes to population displacement data, the Croatian government tracked the movements of displaced persons - primarily Croats expelled from occupied territories, as well as refugees coming from Bosnia and Herzegovina - throughout the war reasonably well, considering the circumstances. In the immediate post-war period, several government publications summarised those figures (e.g. Uprava za prognanike i izbjeglice, 1995), though their calculations must be treated cautiously due to various reporting problems. The two post-war censuses, however, offer a much better and more reliable alternative. In the 2001 census, the Croatian $\mathrm{Bu}-$ reau of Statistics recorded information on individuals' reasons for migration, with one category being "war" in the period between 1991 and 2001. The 2011 census unfortunately abandoned this terminology and instead opted for the category of "forced migration", rendering the two figures not fully comparable, though both very useful. Disability figures from the two censuses, on the other hand, are comparable. Disaggregated by causes of physical or mental disability, with one of the causes being the 1991-1995 war, they offer arguably 
the best insight into the surviving population's exposure to war violence.

Data on deaths and the loss of physical capital in the Croatian war, however, are not as reliable. That is particularly the case when it comes to the data on actual physical destruction. The government did conduct estimates of physical destruction throughout the war and in the immediate post-war period in concert with the promulgation of the Reconstruction Law (Zastupnički dom, 1996). The housing stock damages were, however, estimated only on the level of counties and the methodology used, as well as the real and obvious obstacles, do not suggest we can have full confidence in those figures (Vlada, 1998). Unfortunately, housing stock census data is also of little help due to limited descriptiveness of the categories used. Data on war deaths is in somewhat better shape, with substantial improvements to come in the short- to medium-term with the progress in the completion of the lists of war dead by several non-governmental institutions, as well as the Croatian Memorial and Documentation Centre of Homeland War (HMDCDR) which has arguably come the furthest in this effort, though its work is still incomplete. Aggregate-level data on war veterans, on the other hand, exists only on the level of Croatia's 21 counties (Šućur et al. 2017) and with the recent closing of the Registry of War Veterans to the public through the new Law on War Veterans (Hrvatski Sabor 2017), that is likely to remain the case unless there is a change of policy or a change of government.

Our Figure 2 shows four of the aforementioned variables on the map of Croatia's municipalities. Their analytical potential is immediately apparent. The displacement figures in the upper left map, which are based on the 2011 census data on "forced migration", highlight the geographically uneven influx of former refugees, particularly into Western Slavonia. The most notable feature of the war disability figures in the upper right map, on the other hand, is how the most affected areas closely follow the frontline areas of direct combat, further confirming that this may be the best proxy for the actual exposure of the surviving population to war violence. The bottom two maps, on the other hand, show the still incomplete figures for dead military personnel on both sides of the conflict, acquired from HMDCDR. Soldiers who died on the Croatian side came from nearly all Croatian regions, though disproportionately less from Istria, northern Croatia, and obviously the regions with Serb pre-war majorities. On the other hand, soldiers who died on the side of the rebel Krajina Serbs came exclusively from the areas where the Serbs constituted a majority or significant minority. Although in 1991 Serbs lived throughout the whole of Croatia, the soldiers who died on the side of the rebel Krajina Serbs came from only 107 out of 556 municipalities. Apart from Osijek, almost none of them came from larger urban areas, signifying to which extent the rebellion was territorially determined and to which extent it divided not only Croatia, but also the Croatian Serb community.

In spite of the available data's shortcomings and the limitations of conducting aggregate-level research, we believe scholars of all social sciences in the region could and should make better use of these resources in their analyses. They have the potential of not only helping us answer region-specific puzzles - from the nature of political competition to the patterns of post-war economic development - but also shedding light on great theoretical and conceptual debates of our disciplines. Wars are, indeed, unevenly distributed social events. Their legacies echo in space and time - once 
again, unevenly - for generations after the violence has ended.

\section{Conclusions}

As this review has shown, modelling the consequences of war violence is a complex endeavour. The lack of uniformity in the literature is hardly surprising considering the fact that wars have a multitude of effects on individuals, institutions, and communities. These effects are often both highly context specific and simply not captured by either publicly collected data or conventional public opinion research. However, if we are to make progress - theoretically and empirically - in this very promising field and if we are to reach portable conclusions with strong comparative reach, some order needs to be brought to our efforts at capturing the legacies of war. This was indeed the purpose of this article. It was an attempt to organise, categorise, and evaluate the different approaches at modelling the consequences of war violence, particularly in studies of voters, parties, and electoral competition.

We structured our argumentation around three levels of analysis: individual level of voters, institutional level of political parties, and the aggregate level of communities. Our discussion hopefully offered a number of insights, but we believe the following three should be particularly highlighted. First, the study of the impact of legacies of war on political behaviour on the individual level faces two challenges: the appropriate modelling of the individuals' different dimensions of possible war-related psychological distress (which are related to, but distinct from, direct and indirect war experiences), and the design of studies which go beyond conventional public opinion research in order to allow for better causal inference. Second, in the pursuit for a systematic and abundant stream of evidence regarding the evolution of war legacies in the activities of political parties and political entrepreneurs, the text as data approach offers arguably the greatest promise. Recent software and hardware advances already enable us to trace the reflections of war histories in our discourse, as well as their effects on how the past becomes embedded in the present. The main task is to build appropriate corpora and to continuously make theoretical innovations which can enable us to make sense of it all. And third, the modelling of war legacies on the aggregate level has the potential of helping us revise some longheld views in the scholarship on political cleavages and electoral competition. The challenge is, of course, in generating reliable and comparable aggregate-level data across different historical and temporal contexts.

Although we structured our discussion around the three levels of analysis, this should not distract from the task of making meaningful connections among them. The supply and demand sides of the political market are closely interwoven and can only be properly understood in tandem. We also believe that the lessons from our three levels of analysis have one important thing in common: the implication that, if we are to make empirically solid advancements, we need to engage in constructive dialogue across disciplinary divides. The political science modelling of war legacies cannot move forward without employing the newest developments in psychology, economics, history, linguistics, sociology. Wars are complex social events. Grasping their effects is an equally complex endeavour. Nevertheless, it is imperative that we pursue it. Many post-war societies - particularly those in Southeast Europe - are continuously reliving their pasts. Understanding why that is the case is the first step in changing it. 


\section{References}

Adena, Maja, Enikolopov, Ruben, Petrova, Maria, Santarosa, Veronica, Zhuravskaya, Ekaterina. 2015. Radio and the rise of the Nazis in prewar Germany. Quarterly Journal of Economics. (130) 4: 1885-1939.

Allam, Miriam S., Goerres, Achim. 2011. Economics, politics or identities? Explaining individual support for the Euro in new EU member states in Central and Eastern Europe. Europe-Asia Studies. (63) 8: 1399-1424.

Althaus, Scott L., Bramlett, Brittany H., Gimpel, James G. 2012. When war hits home: The geography of military losses and support for war in time and space. Journal of Conflict Resolution. (56) 3: 382-412.

Baker, Kendall L., Dalton, Russell J., Hildebrandt, Kai. 1981. Germany Transformed. Cambridge: Harvard University Press.

Barnes, Samuel H. 1967. Party Democracy: Politics in an Italian Socialist Federation. New Haven: Yale University Press.

Basedau, Matthias, Moroff, Anika. 2011. Parties in chains: Do ethnic party bans in Africa promote peace? Party Politics. (17) 2: 205-222.

Baturo, Alexander, Dasandi, Niheer, Mikhaylov, Slava J. 2017. What drives the international development agenda? An NLP analysis of the United Nations general debate 1970-2016. In 2017 International Conference on the Frontiers and Advances in Data Science, 1-6. http://arxiv.org/ abs/1708.05873.

Biezen, Ingrid van. 2004. Political parties as public utilities. Party Politics. (10) 6: 701-722.

Bille, Lars. 2001. Democratizing a democratic procedure: Myth or reality? Party Politics. (7) 3: 363-380.
Blattman, Christopher. 2009. From violence to voting: War and political participation in Uganda. American Political Science Review. (103) 2: 231-247.

Brakman, Steven, Garretsen, Harry, Schramm, Marc. 2004. The strategic bombing of German cities during World War II and its impact on city growth. Journal of Economic Geography. (4) 2: 201-218.

Bucciol, Alessandro, Zarri, Luca. 2015. The shadow of the past: Financial risk taking and negative life events. Journal of Economic Psychology. (48): 1-16.

Cameron, Lisa, Shah, Manisha. 2015. Risk-taking behavior in the wake of natural disasters. Journal of Human Resources. (50) 2: 484-515.

Canetti, Daphna et al. 2017. Exposure to violence, ethos of conflict, and support for compromise: Surveys in Israel, East Jerusalem, West Bank, and Gaza. Journal of Conflict Resolution. (61) 1: 84-113.

Canetti-Nisim, Daphna et al. 2009. A new stress-based model of political extremism: Personal exposure to terrorism, psychological distress, and exclusionist political attitudes. Journal of Conflict Resolution. (53) 3: 363-389.

Carson, Jamie L., Jenkins, Jefferey A., Rohde, David W., Souva, Mark A. 2001. The impact of national tides and district-level effects on electoral outcomes: The U.S. congressional elections of 1862-63. American Journal of Political Science. (45) 4: 887-898.

CHESDATA. 2018. Chapel Hill Expert Survey. https://www.chesdata.eu/.

Crawford, Beverly, Lijphart, Arend. 1995. Explaining political and economic change in post-communist Eastern Europe. Comparative Political Studies. (28) 2: 171-199. 
Crowley, Jocelyn Elise, Watson, Margaret, Waller, Maureen R. 2008. Understanding "power talk": Language, public policy, and democracy. Perspectives on Politics. (6) 1:71-88.

Davis, Donald R. Weinstein, David E. 2002. Bones, bombs and breakpoints: The geography of economic activity. American Economic Review. (92) 5: 1269-1289.

Della Vigna, Stefano, Enikolopov, Ruben, Mironova, Vera, Petrova, Maria, Zhuravskaya, Ekaterina. 2014. Cross-border media and nationalism: Evidence from Serbian radio in Croatia. American Economic Journal: Applied Economics. (6) 3: 103-132.

Dewan, Torun, Squintani, Francesco. 2016. In defense of factions. American Journal of Political Science. (60) 4: 860881.

Dyrstad, Karin. 2012. After ethnic civil war: Ethno-nationalism in the Western Balkans. Journal of Peace Research. (49) 6: 817-831.

Dyrstad, Karin. 2013. Does civil war breed authoritarian values? An empirical study of Bosnia-Herzegovina, Kosovo and Croatia. Democratization. (20) 7: 1219-1242.

Eckel, Catherine, El-Gamal, Mahmoud A., Wilson, Rick K. 2009. Risk loving after the storm: A Bayesian-network study of Hurricane Katrina evacuees. Journal of Economic Behavior and Organization. (69) 2: 110-124.

Gabel, Matthew J., Palmer, Harvey D. 1995. Understanding variation in public support for European integration. European Journal of Political Research. (27) 1: 3-19.

Gabel, Matthew J. Whitten, Guy D. 1997. Economic conditions, economic perceptions, and public support for European integration. Political Behavior. (19) 1: 81-96.
Gadjanova, Elena. 2015. Measuring parties' ethnic appeals in democracies. Party Politics. 21 (2): 309-327.

Gartner, Scott Sigmund. 2008. Ties to the dead: Connections to Iraq War and 9/11 casualties and disapproval of the president. American Sociological Review. (73) 4: 690-695.

Gartner, Scott Sigmund, Segura, Gary M., Wilkening, Michael. 1997. All politics are local: Local losses and individual attitudes toward the Vietnam War. Journal of Conflict Resolution. (41) 5: 669-694.

Glaurdić, Josip, Vuković, Vuk. 2015. Prosperity and peace: Economic interests and war legacy in Croatia's EU referendum vote. European Union Politics. (16) 4: 577-600.

Glaurdić, Josip, Vuković, Vuk. 2016. Voting after war: Legacy of conflict and the economy as determinants of electoral support in Croatia. Electoral Studies. (42): 135-145.

Glaurdić, Josip, Vuković, Vuk. 2018. Post-war voters as fiscal liberals: local elections, spending, and war trauma in contemporary Croatia, East European Politics. (34) 2: 173-193

Goeke, Martin. 2016. Political stability and peace through party engineering: The case of Lesotho. Politikon. (43) 3: 293-309.

Grossman, Guy, Manekin, Devorah, Miodownik, Dan. 2015. The political legacies of combat: Attitudes toward war and peace among Israeli ex-combatants. International Organization. (69) 4: 981-1009.

Hadzic, Dino, Carlson, David, Tavits, Margit. 2017. How exposure to violence affects ethnic voting. British Journal of Political Science. Online first.

Healy, Andrew, Malhotra, Neil. 2013. Retrospective voting reconsidered. Annual Review of Political Science. 16: 285-306. 
Hershey, Marjorie R. 2017. Party Politics in America. New York: Routledge.

Hirsch-Hoefler, Sivan et al. 2016. Conflict will harden your heart: Exposure to violence, psychological distress, and peace barriers in Israel and Palestine. British Journal of Political Science. (46) 4: 845-859.

Hrvatski sabor. 2017. Zakon o hrvatskim braniteljima iz Domovinskog rata i članovima njihovih obitelji. Narodne novine. 121/2017.

Ishiyama, John. 2014. Civil wars and party systems. Social Science Quarterly. (95) 2: 425-447.

Ishiyama, John, Marshall, Michael C. 2015. Candidate recruitment and former rebel parties. Party Politics. (21) 4: 591-602.

Itzkovitch-Malka, Reut, Hazan, Reuven Y. 2017. Unpacking party unity: The combined effects of electoral systems and candidate selection methods on legislative attitudes and behavioural norms. Political Studies. (65) 2: 452474.

Jarstad, Anna K., Sisk, Timothy D. 2008. From War to Democracy: Dilemmas of Peacebuilding. Cambridge: Cambridge University Press.

Jennings, M. Kent, Markus, Gregory B. 1977. The effect of military service on political attitudes: A panel study. American Political Science Review. (71) 1: 131-147.

Karol, David, Miguel, Edward. 2007. The electoral cost of war: Iraq casualties and the 2004 U.S. presidential election. Journal of Politics. (69) 3: 633-648.

Katz, Richard S., Crotty, William J. 2014. Handbook of Party Politics. Los Angeles: Sage.

Khazen, Farid el. 2003. Political parties in postwar Lebanon: parties in search of partisans. Middle East Journal. (57) 4: 605-624.
Kijewski, Sara, Freitag, Markus. 2018. Civil war and the formation of social trust in Kosovo: Posttraumatic growth or war-related distress? Journal of Conflict Resolution. (62) 4: 717-742.

Kim, Young-il, Lee, Jungmin. 2014. The long-run impact of a traumatic experience on risk aversion. Journal of Economic Behavior and Organization. (108): 174-186.

Kitschelt, Herbert, Mansfeldova, Zdenka, Markowski, Radoslaw, Tóka, Gábor. 1999. Post-Communist Party Systems: Competition, Representation, and Inter-party Cooperation. Cambridge: Cambridge University Press.

Klingler, Jonathan D., Chatagnier, J. Tyson. 2014. Are you doing your part? Veterans' political attitudes and Heinlein's conception of citizenship. Armed Forces \& Society. (40) 4: 673695.

Koenig, Christoph. 2015. Loose cannons - War veterans and the erosion of democracy in Weimar Germany. Warwick Economics Research Paper Series, No. 1079.

Kostadinova, Tatiana. 2000. East European public support for NATO membership: Fears and aspirations. Journal of Peace Research. (37) 2: 235249.

Krehbiel, Keith. 1993. Where's the party? British Journal of Political Science. (23) 2: 235-266.

Kriner, Douglas L., Shen, Francis X. 2007. Iraq casualties and the 2006 Senate elections. Legislative Studies Quarterly. (32) 4: 507-530.

Kriner, Douglas L., Shen, Francis X. 2012. How citizens respond to combat casualties: The differential impact of local casualties on support for the war in Afghanistan. Public Opinion Quarterly. (76) 4: 761-770.

Kriner, Douglas, L., Shen, Francis X. 2014. Responding to war on Capitol 
Hill: Battlefield casualties, congressional response, and public support for the war in Iraq. American Journal of Political Science. (58) 1: 157-174.

Lehmann, Pola, Lewandowski, Jirka, Matthieß, Theres, Merz, Nicolas, Regel, Sven, Werner, Annika. 2017. Manifesto Corpus. Version: 2017-1. Berlin: WZB Berlin Social Science Center.

Lesschaeve, Christophe, Glaurdić, Josip. 2018. ELWar Expert Survey. Version 1.0. Available at elwar.uni.lu. Luxembourg: University of Luxembourg.

Lipset, Seymour M., Rokkan, Stein. 1967. Cleavage structures, party systems, and voter alignments: An introduction. In Lipset, Seymour M., Rokkan, Stein (eds.). Party Systems and Voter Alignments: Cross-national Perspectives. New York: Free Press, pp. 1-64.

Lyons, Terrence. 2016. From victorious rebels to strong authoritarian parties: Prospects for post-war democratization. Democratization. (23) 6: 10261041.

Mair, Peter. (ed.) 1990. The West European Party System. Oxford: Oxford University Press.

Mair, Peter. 2004. Party System Change: Approaches and Interpretation. Party System Change: Approaches and Interpretation. Oxford: Oxford University Press.

Malmendier, Ulrike, Nagel, Stefan. 2011. Depression babies: Do macroeconomic experiences affect risk taking? Quarterly Journal of Economics. (126) 1: 373-416.

Manning, Carrie. 2008. The Making of Democrats. New York: Palgrave Macmillan.

Manning, Carrie, Smith, Ian. 2016. Political party formation by former armed opposition groups after civil war. Democratization. (23) 6: 972-989.
Marshall, Michael C. 2017. Foreign rebel sponsorship. A patron-client analysis of party viability in elections following negotiated settlements. Journal of Conflict Resolution. Online First.

Marshall, Michael C., Ishiyama, John. 2016. Does political inclusion of rebel parties promote peace after civil conflict? Democratization. (23) 6: 10091025.

Massey, Garth, Hodson, Randy, Sekulic, Dusko. 2003. Nationalism, liberalism and liberal nationalism in post-war Croatia. Nations and Nationalism. (9) 1: 55-82.

Matanock, Aila M. 2018. External engagement: explaining the spread of electoral participation provisions in civil conflict settlements. International Studies Quarterly. (62) 3: 656-670.

Miguel, Edward, Gérard Roland. 2011. The long-run impact of bombing Vietnam. Journal of Development Economics. (96) 1: 1-15.

Montalvo, José. 2011. Voting after the bombings: A natural experiment on the effect of terrorist attacks on democratic elections. Review of Economics and Statistics. (93) 4:1146-1154.

Nenadović, Maja. 2010. An uneasy symbiosis: The impact of international administrations on political parties in post-conflict countries. Democratization. (17) 6: 1153-1175.

Proksch, Sven-Oliver, Slapin, Jonathan B. 2015. The Politics of Parliamentary Debate: Parties, Rebels and Representation. Cambridge: Cambridge University Press.

Ramsbotham, Oliver, Woodhouse, Tom, Miall, Hugh. 2016. Contemporary Conflict Resolution: The Prevention, Management and Transformation of Deadly Conflicts. Cambridge: Polity Press.

Reilly, Benjamin. 2001. Democracy in Divided Societies: Electoral Engineer- 
ing for Conflict Management. Cambridge: Cambridge University Press.

Reilly, Benjamin. 2006. Democracy and Diversity: Political Engineering in the Asia-Pacific. Oxford: Oxford University Press.

Reilly, Benjamin. 2008. Post-war elections: Uncertain turning points of transition. In Jarstad, Anna K., Sisk, Timothy D. (eds.) From War to Democracy: Dilemmas of Peacebuilding. Cambridge: Cambridge University Press, pp. 157-181.

Reilly, Benjamin, Nordlund, Per. 2008. Political Parties in Conflict-Prone Societies: Regulation, Engineering and Democratic Development. New York: United Nations University Press.

Rohrschneider, Robert, Whitefield, Stephen. 2009. Understanding cleavages in party systems: Issue position and issue salience in 13 post-communist democracies. Comparative Political Studies. (42) 2: 280-313.

Rozenas, Arturas, Schutte, Sebastian, Zhukov, Yuri. 2017. The political legacy of violence: The long-term impact of Stalin's repression in Ukraine. Journal of Politics. 79(4): 1147-1161.

Sacco, Katiuscia, Galletto, Valentina, Blanzieri, Enrico. 2003. How has the 9/11 terrorist attack influenced decision making? Applied Cognitive Psychology. (17): 1113-1127.

Sandovici, Maria Elena, Listhaug, Ola. 2012. Expectations about the present and future of Bosnia-Herzegovina: Optimism or pessimism? In: Simkus, Albert and Ringdal, Kirsten. (eds.). The Aftermath of War: Experiences and Social Attitudes in the Western Balkans. Burlington: Ashgate, pp. 257268.

Satyanath, Shanker, Voigtländer, Nico, Voth, Hand-Joachim. 2017. Bowling for fascism: Social capital and the rise of the Nazi Party. Journal of Political Economy. (125) 2: 478-526.

Schonhardt-Bailey, Cheryl. 2005. Measuring ideas more effectively: An analysis of Bush and Kerry's national security speeches. PS: Political Science \& Politics. (38) 4: 701-711.

Schreiber, E. M. 1979. Enduring effects of military service? Opinion differences between U.S. veterans and nonveterans. Social Forces. (57) 3: 824-839.

Simkus, Albert. 2007. South East European Social Survey Project (SEESSP), funded by the Western Balkan program of the Research Council of Norway, grant no. 144826/S30.

Sindre, Gyda Marås. 2016. Internal party democracy in former rebel parties. Party Politics. (22) 4: 501-511.

Solomon, Zahava, Lavi, Tamar. 2005. Israeli youth in the Second Intifada: PTSD and future orientation. Journal of the American Academy of Child \& Adolescent Psychiatry. (44) 11: 11671175.

Statistisches Reichsamt. 1933. Die öffentliche Fürsorge im Deutschen Reich in den Rechnungsjahren 1927 bis 1931. Statistik des Deutschen Reichs. Band 421.

Strabac, Zan, Ringdal, Kristen. 2008. Individual and contextual influences of war on ethnic prejudice in Croatia. Sociological Quarterly. (49) 4: 769796.

Šućur, Zoran, Babić, Zdenko, Ogresta, Jelena. 2017. Demografska i socioekonomska obilježja hrvatskih branitelja. Zagreb: Ministarstvo hrvatskih branitelja i Državni zavod za statistiku.

Taleski, Dane. 2012. Within state-building: Studying parties from guerrillas in Croatia and Macedonia. Südosteuropa. Zeitschrift für Politik und Gesellschaft. (60) 4: 536-544.

Teigen, Jeremy M. 2006. Enduring effects of the uniform: Previous military 
experience and voting turnout. Political Research Quarterly. (59) 4: 601-607.

Teigen, Jeremy. 2007. Veterans' party identification, candidate affect, and vote choice in the 2004 U.S. presidential election. Armed Forces \& Society. (33) 3: 414-437.

Thomson, Henry. 2018. Grievances, mobilization, and mass opposition to authoritarian regimes: A subnational analysis of East Germany's 1953 abbreviated revolution. Comparative Political Studies. (51) 12: 1594-1627.

Tucker, Joshua A. 2006. Regional economic voting. Russia, Poland, Hungary, Slovakia and the Czech Republic, 1990-1999. Cambridge: Cambridge University Press.

Uprava za prognanike i izbjeglice. 1995. Prognanici i izbjeglice u Republici Hrvatskoj. Zagreb: Vlada Republike Hrvatske.

Vlada Republike Hrvatske. 1998. Nastavak obnove ratom stradalih područja. Narodne novine. 159/1998.

Vonyó, Tamás. 2012. The bombing of Germany: The economic geography of war-induced dislocation in West German industry. European Review of Economic History. (16) 97-118.
Voors, Maarten J., Nillesen, Eleonora E. M., Verwimp, E. Philip, Bulte, Erwin H., Lensink, Robert, Van Soest, Daan P. 2012. Violent conflict and behavior: A field experiment in Burundi. American Economic Review. (102) 2: 941964.

Waldinger, Fabian. 2016. Bombs, brains, and science: The role of human and physical capital for the creation of scientific knowledge. Review of Economics and Statistics. (98) 5: 811-831.

Whiting, Sophie. 2016. Mainstream revolutionaries: Sinn Féin as a 'normal' political party? Terrorism and Political Violence. (28) 3: 541-560.

Witmer, Frank D. W., O'Loughlin, John. 2009. Satellite data methods and application in the evaluation of war outcomes: Abandoned agricultural land in Bosnia-Herzegovina after the 1992-1995 conflict. Annals of the Association of American Geographers. (99) 5: 1033-1044.

Zastupnički dom Republike Hrvatske. 1996. Zakon o obnovi. Narodne novine. 24/1996.

Zeeuw, Jeroen de. 2008. From Soldiers to Politicians: Transforming Rebel Movements after Civil War. Boulder: Lynne Rienner. 


\section{Modeliranje naslijeđa ratnog nasilja: birači, stranke, zajednice}

Sažetak Ratovi su ekstremni događaji koji ostavljaju duboke socijalne posljedice. Politička znanost ima ograničen uvid u njihov utjecaj na prirodu i sadržaj političkog natjecanja neposredno nakon što se završe. Djelomice je tako zato što nedostaje pojmovna jasnoća u evidentiranju posljedica rata pomoću pouzdanih podataka. U ovome članku usustavljuju se i vrednuju pokušaji modeliranja posljedica rata u politološkim istraživanjima koja se temelje na kvantitativnim metodama. Razmatranje je organizirano na trima analitičkim razinama: individualnoj razini birača, institucionalnoj razini političkih stranaka i agregatnoj razini zajednica. Posebnu pozornost posvećujemo modeliranju naslijeđa najrecentnijih ratova u Jugoistočnoj Europi, a iznosimo i vlastito gledište o tome koja nastojanja imaju najveći potencijal da pomognu u stvaranju temelja obećavajućega istraživačkog programa.

Ključne riječi naslijeđa rata, postkonfliktna društva, izbori, birači, stranke, političko natjecanje 
